\title{
AN ASSESSMENT OF PRE-SERVICE LANGUAGE TEACHERS' PRACTICUM OBSERVATION FORMS: DESCRIPTIVE OBSERVATION VS. CRITICAL OBSERVATION
}

\author{
Bilal Genc ${ }^{1}$ \\ Kagan Buyukkarci ${ }^{2}$ \\ ${ }^{1}$ English Language Teaching Department, University of Inonu, Malatya, Turkey. \\ ${ }^{2}$ English Language Teaching Department, Suleyman Demirel University, Isparta, Turkey.
}

\begin{abstract}
:
Practicing the role of teacher and auditing/observing experienced teachers are essential parts of practicum studies of pre-service teachers. Regarding observation we differentiate between two kinds of practice: descriptive observation and critical observation. In this paper we reported on 38 pre-service teachers' weekly practicum study observation reports of the classes they taught and audited over a twelve week period during their practicum study. The study examined the level of critical observation in the observation forms of pre-service teachers over twelve weeks' period. Results showed that pre-service teachers mostly focused on the identification of techniques and strategies their cooperating teachers employed and only rarely were critical regarding the cooperating teachers' lesson preparation, classroom management, communication with her/his students and his/her using methods and techniques during the classes. This paper discusses the drawbacks of simple, descriptive observation and provides guiding questions to help pre-service teachers conduct critical observations in their practicum study.
\end{abstract}

Keywords: Observation; language teacher education; pre-service teacher; practicum study.

Corresponding author: Bilal Genc, Ph.D.

E-mail: billgenc@gmail.com

Submitted for publication 18/02/2013

Accepted for publication 03/05/2013

Educational Research eJournal- ISSN 2254-0385

(C) Faculty of Education. University of Alicante

DOI: 10.5838/erej.2013.22. 01 


\section{Introduction}

In Turkey, language teacher education programs are offered by both education faculties and arts and science faculties of universities. As an obligatory part of the curriculum pre-service teachers attend practicum study for one semester and keep a $\log$ in which they write on their observation they conduct during their practicum. The practicum lasts for one semester during which pre-service teachers takes turns to teach their mentor's students who are seventh or eighth year primary school pupils. The observation forms have five sections: a) lesson plan and the cooperating teacher's preparation for the lesson, b) the methods and techniques employed, c) communication,d)classroom management, and e) comments. Each week for four hours pre-service teachers visit their primary or secondary school and take turns in teaching classes and after auditing the cooperating teacher's classes fill out observation forms. Preservice teachers register for teaching practicum for a semester. Most of them work in primary or secondary schools and they receive support, on the one hand, from their university counsellor; on the other, from the school cooperating teacher.

Zeichner suggests (1990) field experiences are significant means through which to develop prospective teachers' understanding of the why, what, and how of teaching and learning. However, simply placing pre-service teachers in the field does not automatically result in a valuable experience for the teacher candidate. The purpose of this study is to evaluate the extent of critical observation, which can be defined as skilled and active interpretation and evaluations of observations in the observation forms of pre-service teachers.

\subsection{Related Research}

Observing experienced teachers is an essential part of most teaching practicum programs around the world. The basic appeal for observation is that with its tangible effects it seems to be a relatively simple activity to organize and it is a way of mastering specific types of behaviours which are observable in the lessons of good teachers (Richards, 1998). Preservice teacher preparatory programs generally combine observation and other research activities to help participants in their initial encounters with their future profession and with no doubt, observation as a key element in teachers' investigation emerges as one of the most important practices to help future teachers learn (Gonzalez, 2005).

Baek and Ham (2009) suggest that recent researches on teaching practicum focuses on four themes: a) pre-service teacher's satisfaction, b) pre-service teacher's teaching performance, c) pre-service teacher's efficacy and d) pre-service teacher's understanding school as a field. Focusing on a different aspect, Baek and Ham (2009) then investigates the educational value of teaching practicum in secondary school. Referring to the results Bake and Ham argued that the teaching practicum had significantly improved pre-service teachers' practical teaching competence, readiness for teacher, and maturity in character, which implies that teaching practicum, is essentail in language teacher education programs. Regarding observation in language teacher education programs, Lally and Veleba (2000) draw our attention to the limited guidance and support given to pre-service teachers and offers keeping teaching diaries which can be used as an observation tool.

Regarding the drawbacks of evaluation forms filled out during or after observation session Conle (1999) gives an example from her own faculty. She argues that the evaluation form they 
devised at their faculty reinforces the perception that good teaching requires performance in front of the students; this is only a perception and not a general truth. When she discussed with her colleagues they also thought that the form did not seem to suit their teaching either. In addition to such deficiencies, the theory or methodology of teaching a particular cooperating teacher influences the observation of pre-service teacher: that two teachers' classroom behaviours change in accordance with their philosophy of teaching causes pre-service teachers give contradictory accounts of the same event (Richards, 1998). Therefore, as a solution to this problem Richards (1998) suggests that:

In using classroom observation in language teacher programs, it is therefore necessary to go beyond a focus on the identification of the techniques and strategies experienced teachers employ and to use observation as a way of collecting information that can be used to develop a deeper understanding of how and why teachers teach the way they do and the different ways teachers approach their lessons (p. 142).

"Going beyond a focus on the identification of the techniques and strategies experienced teachers employ" entails a formal observation which, according to Day (1990), can help preservice teachers in:

-Developing a terminology for understanding and discussing the teaching process

-Developing an awareness of the principles and decision making that underlie effective teaching

-Distinguishing between effective and ineffective classroom practices

-Identifying techniques and practices student teachers can apply to their own teaching.

Thus, while on the one hand the purpose of this study is to assess the observation forms filled out by pre-service teachers during practicum study, on the other hand it provides a rubric to guide the prospective pre-service teachers. The rubric questions prepared aim to elicit multiple perspectives and generate various answers.

\section{Method}

\subsection{Participants}

The participants in this study were 38 students (24 females and 14 males ranging between 21-25 years of age); senior Turkish pre-service teachers of English studying at the English Language and Literature Department of Kafkas University. They are graduates of either private or state secondary schools from all over Turkey. Therefore, they share common cultural characteristics. In the Spring Semester of 2009-2010 Academic Year, pre-service teachers registered for teaching practicum and were involved in classroom observations; they twice or three times had the opportunity to gain some practical teaching experience before they graduated.

\subsection{Instruments}

In this study, 38 files in which observation forms filled out by 38 preservice teachers from the English Language and Literature Department of Kafkas University were analyzed. Preservice teachers were required to write down lesson plans and fill out observation reports. The observation reports consist of two main parts: a) lesson plan and procedure b) observation form. In the lesson plan a brief summary of what has been done in the class and some factual information are given such as subject of the lesson, the students which will cover the subject, duration of class time, etc. The observation forms have five sub headings: a) lesson plan and the mentor teacher's getting prepared for the lesson, b) the methods and techniques employed, 
c) communication, d) classroom management, and e) comments. In analyzing those papers we tried to find answers to the following research questions:

1. What do pre-service teachers write in their practicum study observation forms?

2. To what extent is their observation critical or descriptive?

Since either the pre-service teachers were sometimes absent from the observation sessions or thinking what they wrote in the lesson plan and procedure section enough they did not write anything in the observation form, the total number of observation forms submitted within those 38 files was 420 . Hence, out of 456 expected forms only 420 forms were submitted to the researcher.

\subsection{Data analysis}

All observation forms filled out by the participants in this study were analyzed using content analysis. Using this method the researcher searched through the data for and recurring themes emerging in five subheadings were identified. At the first stage, we tried to categorize each response as descriptive or critical referring to a model prepared $\mathrm{Ho}$ and Richards (1993; qtd in Liou 2001). The responses explaining how the teachers get prepared and make lesson plan; and which methods/techniques are applied in the classroom; the content of the lesson and the patterns of communication are labelled as Descriptive Observation (DO). On the other hand, responses providing personal opinions and justifications, or evaluating the lesson are labelled as Critical Observation (CO). In other words, the responses related providing factual information are categorized as DO, whereas those revealing student teacher's beliefs, ideas, thoughts about the issues dealt with in the observation sheet are categorized as CO. As the second step, for each re-emerging theme (time-of-mention=ToM), a frequency test was run utilizing the Statistical Package for Social Sciences (SPSS) computer program.

\section{Results and discussion}

As there are five sections in the observation form, we analyzed the responses in five subheadings titled as Item 1 to Item 5 . In tables of the each subheading we provided the frequencies and percentages of the responses given.

Item 1: Responses to the lesson plan and the cooperating teacher's preparation for the class.

The first section of the observation sheet is about the cooperating teacher's lesson plan and getting prepared for the class. Themes emerged in the participants' response sheets are teacher's following textbook as a lesson plan (DO), teacher's bringing materials such as tape recorder, puppet, etc to the classroom (DO), and pre-service teachers' evaluations of the lesson plan $(\mathrm{CO})$.

\begin{tabular}{|c|c|c|c|c|}
\hline Item & & Themes & ToM & $\%$ \\
\hline \multirow{3}{*}{\multicolumn{2}{|c|}{$\begin{array}{l}\text { 1. Lesson } \\
\text { plan- } \\
\text { Getting } \\
\text { prepared } \\
\text { for the } \\
\text { lesson }\end{array}$}} & $\begin{array}{l}\text { 1. Cooperating teacher's sticking to } \\
\text { textbook as a lesson plan }\end{array}$ & 345 & 73.9 \\
\hline & & $\begin{array}{l}\text { 2. Cooperating teacher's bringing } \\
\text { materials such as tape recorder, } \\
\text { puppet, etc to the classroom }\end{array}$ & 81 & 17.3 \\
\hline & & $\begin{array}{l}\text { 3. Pre-service teachers' evaluations of } \\
\text { the lesson plan }\end{array}$ & 41 & 8.8 \\
\hline
\end{tabular}

Table 1. Responses to the first section. 
Having a look at Table 1, we can see that Theme 1 emerged 345 times in the observation sheets $(73.9 \%)$ and Theme 2 emerged with 17.3 percentage. Theme 3 which reflects a critical observation emerged with only 8.8 percentages. We present the following verbatim excerpts from the sheets of preservice teachers:

The teacher does not make a lesson plan because s/he follows the textbook. (Theme 1)

The teachers bring to the classroom a puppet to take the attention of the students. (Theme 2)

The teacher has a successful lesson plan. (Theme 3)

Item 2: Responses on the methods and techniques employed.

The second section of the observation sheet is about the cooperating teacher's making use of foreign language methods and techniques. Themes emerged in the participants' response sheets are teacher's making use of certain methods/techniques (DO), and pre-service teachers' evaluations $(\mathrm{CO})$.

\begin{tabular}{|c|c|c|c|}
\hline Item & Themes & ToM & $\%$ \\
\hline \multirow[t]{2}{*}{$\begin{array}{l}2 . \text { The } \\
\text { methods and } \\
\text { techniques } \\
\text { employed }\end{array}$} & $\begin{array}{l}\text { 1. Teacher's making use of certain } \\
\text { methods (Grammar, Translation, } \\
\text { Audio-lingual, Eclecticism) and } \\
\text { techniques (question and answer, relia, } \\
\text { discussion groups, etc) }\end{array}$ & 294 & 70,0 \\
\hline & 2. Pre-service teachers' evaluations & 126 & 30,0 \\
\hline
\end{tabular}

Table 2. Responses to the second section.

When we have a look at Table 2, we can see that Theme 1 emerged 294 times in the observation sheets 70.0 and Theme 2 emerged with 30.0 percentages. The following are verbatim excerpts from the response sheets of pre-service teachers:

Various methods were made use of. (Theme 1)

Grammar-translation and direct method were used. (Theme 1)

Methods/techniques appropriate for the students and subject were used. (Theme 2)
The teacher used question-answer or role play techniques successfully. (Theme 2)

Item 3: Responses on the communication in the classroom.

For this section themes emerged in the participants' response sheets are efficient/successful communication (CO), teacher-student or student-student communication (DO) teacher; the teacher governs the class (CO) and appropriate classroom atmosphere (CO).

\begin{tabular}{|c|c|c|c|}
\hline Item & Themes & ToM & $\%$ \\
\hline \multirow{4}{*}{ 3. Communication } & $\begin{array}{l}\text { 1. Teacher-student or student-student } \\
\text { communication was observed }\end{array}$ & 192 & 43.6 \\
\hline & $\begin{array}{l}\text { 2. Cooperating teacher had } \\
\text { efficient/successful } \\
\text { communication with the students }\end{array}$ & 107 & 24.3 \\
\hline & $\begin{array}{l}\text { 3. The cooperating teacher governed } \\
\text { the class }\end{array}$ & 89 & 20.2 \\
\hline & $\begin{array}{l}\text { 4. There was an appropriate } \\
\text { classroom atmosphere }\end{array}$ & 52 & 11.8 \\
\hline
\end{tabular}


As can be seen in Table 3, we can see that Theme 1 emerged 192 times in the response sheets (43.6\%) and Theme 2 emerged with 24.3 percentages. Theme 3 and 4 emerged with 20.2 and 11.8 percentages, respectively. We present the following verbatim excerpts from the response sheets of participants:

Teacher-student and student-student communications were established. (Theme 1)

The teacher has a very successfulefficient communication with the classroom. (Theme 2)
The teacher has full control over the class. (Theme 3)

There is an appropriate atmosphere for teaching learning activities. (Theme 4)

\section{Item 4: Responses regarding classroom management.}

For this section themes emerged in the participants' response sheets are evaluation of the teacher's management (CO), evaluation of the atmosphere in the classroom (CO), and teacher's control in the classroom $(\mathrm{CO})$.

\begin{tabular}{|c|c|c|c|}
\hline Item & Themes & ToM & $\%$ \\
\hline \multirow{3}{*}{$\begin{array}{l}\text { 4. Classroom } \\
\text { Management }\end{array}$} & 1. The teacher's control in the classroom & 197 & 44,7 \\
\hline & 2. Evaluation of the atmosphere & 157 & 35,6 \\
\hline & 3. Evaluation of the teacher's management & 87 & 19,7 \\
\hline
\end{tabular}
Table 4. Responses to the fourth section.

Having a look at this table, we can see that Theme 1 emerged 197 times in the observation sheets $(44.7 \%)$ and Theme 2 emerged with 35.6 percentages. The least emerged theme was Theme 3 with 19.7 percentage. We present the following verbatim excerpts from the response sheets of participants:

The teacher has full control over the class. (Theme 1)

The teacher employs a successful/efficient management. (Theme 2)

The atmosphere is quite appropriate for teaching \& learning activities. (Theme 3)

Item 5: Pre-service teachers' comments about the class they attend.
Out of 38 pre-service teachers only three of them wrote down on the comments section because they seemed to be confused about what to write on this section. Since there was no instruction for how to fill out that section -the only thing pre-service teachers saw in the heading was "Comments"- they seemed not to be sure what to write in that section. This is because we have also skipped out this section from the rubric (see Appendix A for details) prepared for pre-service teachers. For this section themes emerged in the participants' response sheets are evaluation of the cooperating teacher's teaching (CO), use of materials and methods (CO) and personal feelings (DO).

\begin{tabular}{|c|c|c|c|}
\hline \multirow[t]{4}{*}{ Item } & Themes & ToM & $\%$ \\
\hline & 1. Students teachers' personal feelings & 13 & 24.1 \\
\hline & $\begin{array}{l}\text { 2. Pre-service teachers' evaluation of } \\
\text { the cooperating teacher's teaching }\end{array}$ & 22 & 40.7 \\
\hline & $\begin{array}{l}\text { 3. Pre-service teachers' comment on } \\
\text { the use of materials and methods }\end{array}$ & 19 & 35.2 \\
\hline
\end{tabular}
Table 5. Responses to the fifth section. 
As can be seen in Table 5, we can see that Theme 1 emerged 22 times in the response sheets $(40.7 \%)$ while Theme 2 and Theme 3 emerged with 35.2 and 24.1 percentages, respectively. We present the following verbatim excerpts from the response sheets of participants:

I feel very excited because I regard this day as the first day of my teaching career. (Theme 1)

The teacher established a cheerful learning atmosphere for the students. (Theme 2)

The materials and methods used were in line with the objectives of the lesson. (Theme 3)

As the above presented results display pre-service teachers in this study wrote down mainly descriptive observations for the first, second and third sections of the observation sheet. As the nature of the fourth and fifth sections encourage preservice teachers to evaluate and give their personal feelings, in these sections we see the samples of critical observations. The extent of these critical observations, however, does not go beyond such comments as "successful" or "efficient". One of the most complained points in professional development of teachers is that having getting experienced in teaching most teachers develop routines and it becomes high time for the experienced teacher to criticize himself/herself and engage in professional development. Preservice teacher education seems to the best point at which we could tell our students that everybody is in constant need of change in order to adapt to the changing conditions, even teachers of all branches need to reflect on and make necessary amendments on his/her way of teaching. Hence before assuming a critical attitude for his/her own teaching, pre-service teachers should learn and practice criticizing their mentor teacher's teaching.

As with Conle's (1999) criticism of the evaluation form mentioned in her study, which was devised at their faculty and reinforces the perception that good teaching requires performance in front of the students; the form devised in our faculty seems not to provide pre-service teachers with enough guidance as to filling out the forms. Therefore, we have prepared a rubric to be referred to before beginning observation sessions in practicum study (see Appendix A for details). The questions in the rubric both helps the Turkish students who are to prepare such a report mentioned in this study and also to pre-service language teachers all around the world who are to observe language classes and write reports after observation sessions during the practicum study.

\section{Conclusion}

This study documented what pre-service teachers wrote in filling out their observation forms during the practicum study. The participant pre-service teachers filled out "observation forms" as a part of their practicum study and wrote both factual and evaluative remarks, albeit few, in those observation reports.

They, however, wrote mainly on what was going on in the classroom summarizing, not reflecting, this is what many k-12 students do as well without evaluating or judging the lesson plan, methods/techniques used, the communication in the classroom and the teacher's classroom management. We believe that teacher educators' one of the major contributions would be fostering pre-service teachers to engage in critical observation processes for their own professional development and transform the language classroom.

In conclusion, these findings highlight the need to expand critical questioning/observation activities for pre-service teachers' personal and professional development. The findings of this study support the claim that observation guidelines 
should be tailored to engage pre-service teachers in critical thinking. Furthermore we believe that in a follow up study we should explore why the participants of this study did not evaluate and judge the lesson plan, methods/techniques used, the communication in the classroom and the teacher's classroom management, and only described what was going on in the classroom. Through a retrospective interview with the participants the main reason could be found out precisely.

\section{References}

Baek, S-G., \& Ham, E. H. (2009). An Evaluation Study on the Educational Value of Teaching Practicum in Secondary School. Asia Pacific Educational Review,10(2), 271-280.

[Back to text] [Abstract]

Conle, C. (1999). Moments of interpretation in the perception and evaluation of teaching. Teaching and Teacher Education, 15, 801-814. [Back to text] [Full text]

Day, R. (1990). Teacher Observation in Second Language Teacher Education. In J. C. Richards \& D. Nunan (eds.), Second Language Teacher Education (pp.43-61). New York: Cambridge University Press. [Back to text] [Abstract]

Gonzalez, J. J.V. (2005). Responding to Observation: How Student Teachers' Use of their Counselor's Notes Support their Preparation. Profile, 6, 141-156.
[Back to text] [Full text]

Ho, B., \& Richard, J. C. (1993). Reflective Thinking through Teacher Journal Writing: Myths and Realities. Prospect, 8, 7-24. [Back to text] [Abstract]

Lally, C. G., \& Veleba, K. (2000). Language Teacher Observation and Reflective Diaries: An Alternate Perspective. Education, 121(1), 106-113. [Back to text] [Abstract]

Liou, H. C. (2001). Reflective practice in pre-service teacher education program for high school English teachers in Taiwan, ROC. System, 29(2), 197-208. [Back to text] [Full text]

Murphy, J. M. (2001). Reflective Teaching. In M.Celce-Murcia (Ed.), Teaching English as a Second or Foreign Language. (pp.499-514). USA: Heinle \& Heinle. [Back to text]

Richards, J. C. (1998). Beyond Training: Perspectives on Language Teacher Education. Cambridge: Cambridge University Press. [Back to text] [Abstract]

Zeichner, K. (1990). Changing directions in the practicum: Looking ahead to the 1990s. Journal of Education for Teaching, 16(2), 105-132. [Back to text] [Abstract] 


\section{APPENDIX A}

\begin{tabular}{|c|c|}
\hline $\begin{array}{l}\text { A. Lesson plan and getting prepared } \\
\text { for the lesson } \\
\text { - Why do we need lesson } \\
\text { plans? } \\
\text { - Are textbooks and other } \\
\text { materials interesting and } \\
\text { useful? } \\
\text { - } \text { Do they help students to } \\
\text { practice and improve their } \\
\text { language skills? } \\
\text { - } \quad \text { Does the lesson plan } \\
\text { include such important } \\
\text { elements as the objectives, } \\
\text { assessments, class } \\
\text { activities? } \\
\text { - How does a lesson plan } \\
\text { help teacher to achieve } \\
\text { his/her goals? } \\
\text { What do you think are the } \\
\text { benefits and difficulties of } \\
\text { preparing a lesson plan? }\end{array}$ & $\begin{array}{l}\text { B. Methods and techniques employed } \\
\text { - Which techniques of the method } \\
\text { the teacher employs are used? } \\
\text { - What is students' reaction to } \\
\text { methods and techniques used? } \\
\text { Do they look bored and } \\
\text { frustrated, or enthusiastic and } \\
\text { interested? } \\
\text { - In your opinion, for which } \\
\text { techniques/methods are the } \\
\text { materials for? } \\
\text { - What do you think are the } \\
\text { strengths and limitations of the } \\
\text { methods and techniques used? }\end{array}$ \\
\hline $\begin{array}{l}\text { C. Communication } \\
\text { - } \text { Do the lessons usually } \\
\text { begin and end in the same } \\
\text { way? } \\
\text { - } \text { How do students respond } \\
\text { to teacher feed back? } \\
\text { - How does the teacher } \\
\text { draw a lesson to a close? } \\
\text { - How do the teacher and } \\
\text { the class move from one } \\
\text { activity to another? } \\
\text { Do the learners ask for } \\
\text { clarification and how? } \\
\text { - How does the teacher give } \\
\text { instruction, respond to } \\
\text { students' errors, and work } \\
\text { with reluctant learners? } \\
\text { Do the learners have an } \\
\text { impact on classroom } \\
\text { activities? } \\
\text { Are there learners who are } \\
\text { relatively more or less } \\
\text { participatory during } \\
\text { particular lesson phases? }\end{array}$ & $\begin{array}{l}\text { D. Classroom management } \\
\text { - What are some characteristics of } \\
\text { the teacher's instructional style } \\
\text { that work well? And what are } \\
\text { some characteristic you find to be } \\
\text { less helpful? } \\
\text { - How does the teacher allot time } \\
\text { within a lesson? } \\
\text { - How does the teacher assign ask } \\
\text { to students? } \\
\text { - How does the teacher reinforce } \\
\text { student answers? } \\
\text { - How does the teacher supervise } \\
\text { students while they are learning } \\
\text { How does the teacher handle } \\
\text { misbehaviour and off-task } \\
\text { behaviour? }\end{array}$ \\
\hline
\end{tabular}

Guidelines for Observation Form (with questions partly adapted from Murphy, 2001 and Richards, 1998). 